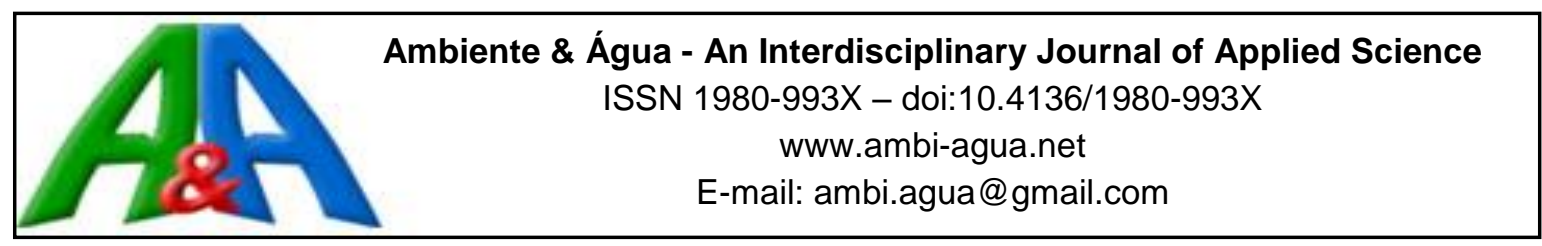

\title{
Efficient degradation of solid yeast biomass from ethanol industry by Fenton and UV-Fenton processes applying multivariate analysis
}

\author{
doi:10.4136/ambi-agua.2124
}

Received: 24 Apr. 2017; Accepted: 31 Jul. 2017

\section{Geórgia Labuto $^{1 *}$; Lilia Ribeiro da Silva ${ }^{1}$; Heron Dominguez Torres da Silva ${ }^{1}$; Elma Neide Vasconcelos Martins Carrilho²; Norberto Sanches Goncalves; Christiane de Arruda Rodrigues ${ }^{4}$}

\author{
${ }^{1}$ Universidade Federal de São Paulo (UNIFESP), Diadema, SP, Brasil \\ Grupo de Análises Químicas Aplicadas. E-mail: geolabuto@gmail.com \\ liliarsilva-mg@hotmail.com, heron.fsa@gmail.com \\ ${ }^{2}$ Universidade Federal de São Carlos (UFSCar), Araras, SP, Brasil \\ Departamento de Ciências da Natureza, Matemática e Educação. E-mail: elma.carrilho@gmail.com \\ ${ }^{3}$ Universidade Federal de São Paulo (UNIFESP), Diadema, SP, Brasil \\ Laboratório de Química de Calixarenos, Espectroscopia Molecular e Catálise. E-mail: nsgoncal@gmail.com \\ ${ }^{4}$ Universidade Federal de São Paulo (UNIFESP), Diadema, SP, Brasil \\ Laboratório de Engenharia e Controle Ambiental. E-mail: chris.arruda72@gmail.com \\ *Corresponding author
}

\begin{abstract}
Organic agro-industrial residues have been successfully used as biosorbents and promoting new uses from agricultural wastes benefits the economy. However, the allocation of a solid waste biosorbent after the sorption of contaminants has limited their effective application on a large scale as an alternative treatment of water and wastewaters. One solution could be degradation to convert the biosorbent material and adsorbed organic contaminants into environmental friendly compounds suitable for discharge. This study used an experimental design to evaluate the Fenton degradation of yeast biomass (YB) from the alcohol industry as a potential biosorbent. The efficiency of degradation was monitored according to the degraded mass (DM) and total organic carbon (TOC) remaining in the solution. The ANOVA showed an error of $9.7 \%$ for the effects and the media of interaction for the employed model for DM. Conducting the experiments with the best-predicted conditions (60 min, $25 \mathrm{~g}$ of YB, $\mathrm{pH} \mathrm{3}$, $8,000 \mathrm{mg} \mathrm{L}^{-1} \mathrm{H}_{2} \mathrm{O}_{2}$ and $40 \mathrm{mg} \mathrm{L}^{-1} \mathrm{Fe}^{2+}$ ) with $30 \mathrm{~W} \mathrm{UV}$ irradiation resulted in a YB reduction of $72 \pm 2 \%$ with a TOC of $30 \pm 2 \%$. This suggests that an advanced oxidative process is an alternative for degradation of a biosorbent after sorption.
\end{abstract}

Keywords: biosorbent degradation, chemometric approach, oxidative processes, photo-Fenton process, treatment of solid residues.

\section{Degradação de resíduo sólido de biomassa de levedura da indústria de etanol empregando processos Fenton e UV-Fenton assistidos por análise multivariada}

\section{RESUMO}

Resíduos agro-industriais orgânicos têm sido utilizados com sucesso como biossorventes e podem impulsionar a economia promovendo novos usos para os mesmos. Contudo, o destino 
do resíduo sólido gerado pelo biossorvente após a sorção de contaminantes tem sido uma limitação à aplicação em larga escala de tais materiais como alternativa ao tratamento de águas e águas residuais. Processos oxidativos avançados podem ser uma alternativa para converter o material biossorvente, juntamente com contaminantes orgânicos adsorvidos, em compostos amigáveis ao meio ambiente adequados para descarte. No presente trabalho, planejamento experimental foi utilizado para avaliar a degradação da biomassa de levedura (YB) da indústria de álcool, uma biomassa empregada como biossorvente. Através de processos Fenton e UV-Fenton, a eficiência da degradação foi monitorada de acordo com a massa degradada (DM) e o carbono orgânico total (TOC) remanescente na solução. ANOVA mostrou que os processos de degradação são adequados, com erro de $9,7 \%$ para os efeitos e os meios de interação para o modelo empregado para DM. A condução de degradação empregando as melhores condições previstas pelo modelo teórico (60 min, $25 \mathrm{~g}$ de $\mathrm{YB}, \mathrm{pH} 3,8.000 \mathrm{mg} \mathrm{L}^{-1} \mathrm{de}_{2} \mathrm{O}_{2}$ e $40 \mathrm{mg} \mathrm{L}^{-1}$ de $\mathrm{Fe}^{2+}$ ) com irradiação UV de $30 \mathrm{~W}$ resultou numa redução em massa de YB de $72 \pm 2 \%$ com um TOC de $30 \pm 2 \%$. Isto sugere que um processo oxidativo avançado é uma alternativa para a degradação de um biossorvente sólido após sorção.

Palavras-chave: abordagem quimiométrica, degradação de biossorvente, processo foto-Fenton, processos oxidativos, tratamento de resíduos sólidos.

\section{INTRODUCTION}

Biosorption has been suggested as a viable alternative to remove organic and inorganic contaminants from aqueous media, transferring these contaminants to a solid support. In this regard, different kinds of organic matter have been successfully employed as biosorbents, such agro industry residues, vegetal residues, bacteria, algae, fungi and yeasts (Wang and Chen, 2009). This use can benefit the economy, allowing for the recycling of agricultural wastes to new uses (Labuto and Carrilho, 2016). However, the disposal of the biosorbent after sorption remains a challenge, since disposal in landfills, incineration or calcination of the solid residue are not environmentally friendly solutions (Renou et al., 2008; Cortez et al., 2011; Macklin et al., 2011; Li et al., 2010). In addition, these methods disposal are expensive (Guerrero et al.; 2013).

Advanced oxidation processes (AOPs) have been used to degrade landfill material (Umar et al.; 2010; He et al., 2015; Mahmad et al., 2016) and may offer an alternative to partial or complete simultaneous degradation of biosorbent residue and adsorbed organic contaminants. The basic principle of AOP is the formation of free radicals such as $\bullet \mathrm{OH}$, either by chemical, physical, electrochemical, or photochemical means. The hydroxyl radical $(\bullet \mathrm{OH})$ has a high oxidation potential $(\mathrm{E}=2.730 \mathrm{~V})$ and reacts with organic matter, converting it into $\mathrm{CO}_{2}, \mathrm{H}_{2} \mathrm{O}$ and mineral acids (Solozhenko et al., 1995). In general, organic matter dissolved in water is oxidized by a straight chain of reactions (many of which involve free radicals) initiated, for example, by the abstraction of a hydrogen atom in the target pollutant compound by $\cdot \mathrm{OH}$ (Solozhenko et al., 1995). The $\cdot \mathrm{OH}$ radical is formed by the combination of oxidants such as ozone and $\mathrm{H}_{2} \mathrm{O}_{2}$ in the presence of ultraviolet irradiation (UV) or by catalysts such as metal ions or semiconductors.

Despite the high oxidizing power of AOP, its application is focused on the treatment of soluble substances in water and wastewater. However, some studies have reported the use of AOPs for the treatment of solid residues with the objective of waste disposal after biosorption processes, as these materials are usually discarded in landfills or incinerated (Umar et al., 2010; Moravia et al., 2013; Girardi et al., 2014, Li et al., 2016).

The treatment of thickened sludge (6\% of the solids drained) from municipal wastewater treatment plants and industrial effluents has shown that peroxidation is efficient at reducing the amount of residual sludge. However, during this process the attack of free radicals preferably 
releases the fraction of organic dry solids into the aqueous phase. The slight increase in the $\mathrm{BOD} / \mathrm{COD}$ ratio of the filtrate makes this a more biodegradable phase and converts the drained solid into a source of carbon available for nitrification/denitrification (Neyens et al., 2002). Improving the specific resistance to filtration (SRF) of waste-activated sludge with high amounts of solids after Fenton treatments suggests that AOPs can reduce the solid materials present in effluents (Neyens and Baeyens, 2003).

The successful removal of organic matter from landfill leachates was demonstrated described by Li et al. (2010). The authors pointed out the fact that the toxicity relevant to the presence of microorganisms is not a commonly evaluated parameter in degradation studies and recommended that it should be monitored in the future. Studies involving AOPs for the treatment of landfill material are not specifically focused on investigating the degradation of the solid fraction by the microorganisms present in the effluent.

Oxidative treatments have been applied to prepare organic solid waste for subsequent applications. Solid waste from the olive industry has been treated with the main objective of oxidizing the phenolic substances for further use of the waste as a fertilizer (Girardi et al., 2014). The Fenton process has been employed as a pre-treatment to delignify garden biomass in order to destroy lignin and allow the biomass to be used for energy production (Bhange et al., 2015). Many studies have employed chemometric tools to improve the degradation process of landfill organic matter and to determine the optimal ratio between $\mathrm{Fe}^{2+}$ and $\mathrm{H}_{2} \mathrm{O}_{2}$ (Wu et al., 2011, Amiri and Saubor, 2014).

In order to solve the problem of solid residues after biosorption, we evaluated the effect of the Fenton and UV/Fenton processes supported by chemometrics to determine the ideal combination of $\mathrm{H}_{2} \mathrm{O}_{2}, \mathrm{Fe}^{2+}$, organic matter and time to provide the most effective degradation of yeast biomass (YB) from the alcohol industry. Yeasts are a common organic matter employed as a biosorbent and this specific YB has been previously used as a biosorbent for organic and inorganic species in our research group (Labuto et al., 2015; Trama et al., 2014).

\section{MATERIALS AND METHODS}

\subsection{Materials}

The solutions employed in the Fenton and photo-Fenton $\mathrm{YB}$ treatments were prepared from $50 \%$ (v/v) $\mathrm{H}_{2} \mathrm{O}_{2}$ and $\mathrm{FeSO}_{4} .7 \mathrm{H}_{2} \mathrm{O}$ (both Sigma). Diluted solutions of $\mathrm{H}_{2} \mathrm{SO}_{4}$ or $\mathrm{NaOH}$ (Merck, Germany) were used for $\mathrm{pH}$ adjustments.

Previously weighed quantitative Pro nylon $0.45 \mu \mathrm{m}$ filters (Aprolab, Brazil) were used to filter the residues of the oxidative treatments. A TE-420 incubator (Tecnal, Brazil) was used as an agitator in the degradation studies. For the analysis of total organic carbon (TOC), an SSM TOC-5000A analyzer (Shimadzu, Japan) was used. For weighing samples, an analytical balance accurate to five decimal places (Shimadzu, Japan) was used. For the photo-Fenton process, two germicidal lamps with a power of $15 \mathrm{~W}$ (Philips, Brazil) were used.

The yeast biomass (YB) used in the degradation studies was obtained from an alcohol-producing facility in São Paulo. In the biomass characterization, scanning electron microscopy images (SEM) were captured by a Zeiss EVO MA 15 microscope (Zeiss, Germany), and a CHNS-O EA 1108 elemental analyzer (Thermo Scientific, USA) was used for $\mathrm{C}, \mathrm{H}, \mathrm{N}$, and $\mathrm{S}$ determination.

Infrared spectra were obtained by using a micro-attenuated total reflection attachment (MIRacle ${ }^{\mathrm{TM}}$ Pike Instruments). The samples were placed on to a $\mathrm{Zn}$ Se window and pressed to assure a good optical contact. The spectra were rationed against air. 


\subsection{Experimental design to define the best conditions for Fenton degradation}

A central composite design (CCD) was conducted using two treatment times (60 and $90 \mathrm{~min}$ ) with triplicates at the central point. This type of experimental design provides a simple multivariate optimization method with advantages that result in a small number of experiments, faster acquisition of results, good efficiency and the ability to use more than one factor while optimizing (Ferreira and Daniel, 2004; Paterlini and Nigueira, 2005).

The parameters set for assessment were the initial concentrations of $\mathrm{H}_{2} \mathrm{O}_{2}$ and $\mathrm{Fe}^{2+}$, and the initial mass of yeast biomass (YB). These parameters varied at three levels, with a total of 20 experiments, which were carried out in triplicate, totaling 60 experiments. The established levels $\left(-1,0\right.$, and 1) for each evaluated parameter were: $\mathrm{H}_{2} \mathrm{O}_{2}=5,000,7,500$ or $10,000 \mathrm{mg} \mathrm{L}^{-1}$, $\mathrm{Fe}^{2+}=25,37.5$ or $50 \mathrm{mg} \mathrm{L}^{-1}$, and $\mathrm{YB}=25,112.5$ or $250 \mathrm{mg}$.

All experiments were carried out at $\mathrm{pH} 3$, which has been reported in the literature as the best $\mathrm{pH}$ for the Fenton reaction (Umar et al., 2010; Klamerth et al., 2013). The initial concentrations of $\mathrm{Fe}^{2+}$ and $\mathrm{H}_{2} \mathrm{O}_{2}$ were defined by preliminary experiments.

The experimental design allows the determination of the significance and magnitude of the main effects of each factor and their interactions. This stage allowed for the selection of the most important factors to establish the best conditions for the degradation of YB based on statistical criteria.

To conduct the experiments, the YB mass was measured according to the experimental design and then suspended in solutions containing $\mathrm{H}_{2} \mathrm{O}_{2}$ and $\mathrm{Fe}^{2+}$ with the $\mathrm{pH}$ fixed. The suspensions were stirred on a shaker table at $2400 \mathrm{rpm}$ for 60 to $90 \mathrm{~min}$, according to the block corresponding to the sample. After the set time, the samples were filtered through a $45 \mu \mathrm{m}$ filter (70 $\mathrm{mm}$ in diameter) that had been previously weighed. The filters were then dried in an oven at $60^{\circ} \mathrm{C}$ until a constant weight, cooled in a desiccator and weighed to determine the mass of the remaining YB after Fenton treatment, designated as the Fenton residue (FR).

The $\mathrm{pH}$ of the remaining supernatant was increased to 8 by the addition of $1 \mathrm{~mol} \mathrm{~L}^{-1} \mathrm{NaOH}$ in order to interrupt the oxidation process. Next, $3 \mathrm{~mL}$ aliquots of each sample were collected and their volumes were adjusted to $30 \mathrm{~mL}$ with distilled deionized water to quantify the total organic carbon (TOC).

Statistica ${ }^{\mathrm{TM}}$ version 12.7 was used for data analysis. The data matrix obtained by following the experimental design was treated by factor analysis. Multivariate optimization in the initial stage selected the most statistically significant factors for the process. In the second stage, the optimal operating conditions were determined. After the analysis of the experimental design, the data on degraded mass (DM) and TOC were assessed to predict the best conditions for the YB degradation process.

Multivariate calibration methods like partial least squares (PLS), neural networks and multivariate adaptive regression splines (MARS) were also used, and the optimal predicted degradation conditions were employed for the Fenton degradation of YB with and without ultraviolet radiation.

\subsection{Application of ultraviolet radiation to the best Fenton degradation conditions obtained by the experimental design}

The best conditions for Fenton degradation obtained in the experimental design and predicted by MARS were used with UV irradiation employing 30 and $80 \mathrm{~W}$ lamps (Philco and Osran, respectively) arranged in a covered reactor with a reflective surface (60 cm length $\times 30 \mathrm{~cm}$ width $\times 20 \mathrm{~cm}$ depth).

The degradation media was prepared using solutions containing 8,000 $\mathrm{mg} \mathrm{L}^{-1} \mathrm{H}_{2} \mathrm{O}_{2}$ and $40 \mathrm{mg} \mathrm{L}^{-1} \mathrm{Fe}^{2+}$ or $10,000 \mathrm{mg} \mathrm{L}^{-1} \mathrm{H}_{2} \mathrm{O}_{2}$ and $50 \mathrm{mg} \mathrm{L}^{-1} \mathrm{Fe}^{2+}$, both at $\mathrm{pH}$ 3.0. Suspensions containing $25 \mathrm{mg}$ of $\mathrm{YB}$ were prepared by adding of $5 \mathrm{~mL}$ of each reagent, totaling $10 \mathrm{~mL}$ of degradation media. These were placed in Petri dishes $(1 \mathrm{~cm}$ height and $10 \mathrm{~cm}$ diameter). The 
batch procedure was conducted by stirring the samples for $60 \mathrm{~min}$ at a distance of $3 \mathrm{~cm}$ from the UV lamps.

After the period set for the procedure, the lamps and the stirrer were turned off and the residues present in the suspensions following photo-Fenton degradation (PF) were fully filtered employing previously weighed filters $(45 \mu \mathrm{m}, 70 \mathrm{~mm}$ in diameter). After filtration, the filters were dried in an oven at $60^{\circ} \mathrm{C}$, cooled in a desiccator and monitored until a constant weight to determine the weight of the material remaining in the solution at the end of the PF process.

The $\mathrm{pH}$ of the filtrates was adjusted to 8 by the addition of $1 \mathrm{~mol} \mathrm{~L}^{-1} \mathrm{NaOH}$ in order to interrupt the oxidation process (Pontes et al., 2010). Then, $3 \mathrm{~mL}$ aliquots of these solutions were taken and the volume adjusted to $30 \mathrm{~mL}$ with distilled deionized water for TOC quantification.

\subsection{Determination of TOC in the supernatants of samples after the oxidative degradation process}

The TOC concentrations in the supernatants of oxidative degradation samples were determined after acidifying the sample with 1 mol L ${ }^{-1} \mathrm{HNO}_{3}$ to solubilize $\mathrm{Fe}^{2+}$ which might have been precipitated due to the $\mathrm{pH}$ adjustment performed to interrupt the Fenton reaction. A glucose calibration curve with a $250 \mathrm{mg} \mathrm{L}^{-1}$ standard was used to determine the standard deviation of the sample with a maximum $2 \%$ error.

\section{RESULTS AND DISCUSSION}

\subsection{Experimental design to predict the best conditions for Fenton degradation}

Considering the objectives outlined in this work, the main challenges were:

a) To establish the working conditions that would allow the attack of YB by hydroxyl free radicals $(\bullet \mathrm{OH})$ generated by the Fenton reaction or photo-Fenton in order to break and fragment the cellular structure.

b) The maintenance of the $\bullet \mathrm{OH}$-generated attack on $\mathrm{YB}$ even in the presence of solubilized fragments more easily attacked by $\bullet \mathrm{OH}$.

c) Maximum conversion of $\mathrm{YB}$ into $\mathrm{CO}_{2}$ and $\mathrm{H}_{2} \mathrm{O}$.

The monitoring of the process was conducted through the measurement of the degraded mass (DM), the main factor used to evaluate YB degradation, and the total organic carbon (TOC). The degradation efficiency was also accompanied by elemental analysis (CHNS), scanning electron microscopy (SEM), and Fourier Transformed Infra-Red Spectroscopy (FT-IR). The results of DM and TOC from the central composite design (CCD) blocked by time in triplicate at the central point were assessed using Statistica ${ }^{\circledR}$.

A two-way (dual effect) model was used that measures linear and quadratic variation with double effects, considering time as a factor and not as a blocking parameter, which contributed to the explanation of the data. The first evaluation showed a loss of response according to the working block, with the best results for lower TOC and DM obtained after 60 min of degradation time. This can be observed by estimating the effects for both cases (Table 1).

For Block 2, the increase in time to 90 min was a critical factor. An explanation for this may be that there are two reactions that happened simultaneously and added up. The first reaction step is possibly initiated by $\bullet \mathrm{OH}$, resulting from the reaction of $\mathrm{H}_{2} \mathrm{O}_{2}$ and $\mathrm{Fe}^{2+}$. In this step, $\mathrm{H}_{2} \mathrm{O}_{2}$ is consumed intensively due to the catalytic formation of $\bullet \mathrm{OH}$. However, $\mathrm{Fe}^{3+}$ is produced, and may also react with $\mathrm{H}_{2} \mathrm{O}_{2}$ to form weaker radicals with lower oxidizing power $\left(\mathrm{HO}_{2} \bullet\right)$, which contribute to the decreased amount of $\mathrm{H}_{2} \mathrm{O}_{2}$ available to participate in the reaction. As $\mathrm{H}_{2} \mathrm{O}_{2}$ is reduced in the solution, the formation of $\bullet \mathrm{OH}$ is impaired, starting a slow 
reaction step. Thus, as time elapses, $\mathrm{Fe}^{3+}$ increases and reacts with $\mathrm{H}_{2} \mathrm{O}_{2}$, thereby reducing the degradation efficiency (Rigg et al., 1954; Walling and Goosen, 1973).

Table 1. Design of Experiments Analysis blocked in time, without considering the interaction effects. The significant effects are highlighted in red. It shows that block variation significantly influences TOC.

\begin{tabular}{|c|c|c|c|c|c|c|}
\hline & \multicolumn{3}{|c|}{$\begin{array}{c}\text { Effect Estimates for TOC } \\
\mathrm{R}^{2}=0.888 ; 3^{3} \text { level factors } \\
2 \text { Blocks, } 20 \text { Runs. }\end{array}$} & \multicolumn{3}{|c|}{$\begin{array}{c}\text { Effect Estimates for DM } \\
\mathrm{R}^{2}=0.779 ; 3^{3} \text { level factors } \\
2 \text { Blocks, } 20 \text { Runs. }\end{array}$} \\
\hline & Effect & $\mathrm{t}(12)$ & $\mathrm{p}$ & Effect & $\mathrm{t}(12)$ & $\mathrm{p}$ \\
\hline Mean/Interc. & 131.3 & 6.0 & $6.10 \mathrm{E}-05$ & 36.82 & 10.6 & $0.00 \mathrm{E}+00$ \\
\hline Block & -53.1 & -2.4 & $3.29 \mathrm{E}-02$ & -5.62 & -1.1 & $2.84 \mathrm{E}-01$ \\
\hline $\mathrm{H}_{2} \mathrm{O}_{2}(\mathrm{~L})$ & -47.3 & -1.9 & 8.38E-02 & -2.86 & -0.5 & $6.26 \mathrm{E}-01$ \\
\hline $\mathrm{H}_{2} \mathrm{O}_{2}(\mathrm{Q})$ & 27.4 & 1.1 & $2.85 \mathrm{E}-01$ & -4.24 & -0.4 & 7.09E-01 \\
\hline $\mathrm{Fe}(\mathrm{L})$ & -38.3 & -1.5 & $1.53 \mathrm{E}-01$ & 7.09 & 1.2 & $2.38 \mathrm{E}-01$ \\
\hline $\mathrm{Fe}(\mathrm{Q})$ & 3.9 & 0.2 & $8.76 \mathrm{E}-01$ & -17.36 & -1.6 & $1.44 \mathrm{E}-01$ \\
\hline YB (L) & 176.4 & 2.7 & $1.76 \mathrm{E}-02$ & -25.12 & -4.4 & $8.60 \mathrm{E}-04$ \\
\hline YB (Q) & 48.7 & 0.9 & 4.12E-01 & 38.25 & 3.4 & $5.66 \mathrm{E}-03$ \\
\hline \multicolumn{7}{|c|}{ Response variation as a function of time variable* } \\
\hline$(\mathrm{B} 1-\mathrm{B} 2) / \mathrm{R}$ & & 0.83 & & & 0.07 & \\
\hline $\mathrm{B} 1 / \mathrm{R}$ & & 0.99 & & & 0.93 & \\
\hline $\mathrm{B} 2 / \mathrm{R}$ & & 0.17 & & & 0.86 & \\
\hline
\end{tabular}

* $\mathrm{B} 1$ is Block 1 (60 $\mathrm{min}), \mathrm{B} 2$ is Block $2(90 \mathrm{~min})$ and $\mathrm{R}$ is an experimental reference condition $\left(\mathrm{H}_{2} \mathrm{O}_{2}=8,000 \mathrm{mg} \mathrm{L}^{-1}, \mathrm{Fe}=40 \mathrm{mg} \mathrm{L}^{-1}, \mathrm{YB}=25 \mathrm{mg}\right)$.

The model had a relative error (standard error/mean variation of the experimental matrix) of $9.7 \%$ for DM. We believe that the error exceeding $5 \%$ is related to the intrinsic nature of the experiment, which aimed to degrade solid material by the Fenton reaction. The yeast cell wall polysaccharide has glucan (30 to 34\%), mannan (30\%) and complex long-chain polymers resistant to acid and other chemicals (Gomes, 2004) as its main components. The primary interaction of $\bullet \mathrm{OH}$ with yeast first breaks the weakest bonds and enables the conversion of soluble macromolecules.

It is important to emphasize that, kinetically, the chances of a free radical finding a chemical bond in favor of cleavage as it interacts with a solid biological material is infinitely inferior to this phenomenon occurring on a soluble organic molecule. This fact led us to consider that, since soluble molecules are generated from the solid material, the action of free radicals on the solid sample would be reduced, as the action on the solubilized organic molecules would intensify to help reduce TOC.

Observing the marginal means of the graphs (Figure 1A), it is clear that there was a gain in DM for treatments employing smaller initial masses of YB, even without performing the projection of optimal point. Thus, with a shorter period of time, the mass reduction is greater. Moreover, it was observed that the highest levels of $\mathrm{Fe}^{2+}$ and $\mathrm{H}_{2} \mathrm{O}_{2}$ led to greater DM values. For TOC, the marginal means graphs without any statistical treatment (Figure 1B) showed a greater efficiency of degradation when lower mass was used. Moreover, employing a shorter time, and maximum levels of $\mathrm{Fe}^{2+}$ and $\mathrm{H}_{2} \mathrm{O}_{2}$ contributed to lower TOC values.

The $\mathrm{r}^{2}$ values correspond to model regression covering all the experimental data. Considering the DM for YB and observing the Pareto chart and analysis of variance (Supplementary Data), it was found that, for the mass factor both components, i.e. linear and 
quadratic, were statistically significant. This was the only factor that showed significance, standing out as the main factor contributing to the variation in DM. The same was observed for the TOC remaining in the supernatants of the degraded samples.

A) Degraded Mass (DM)
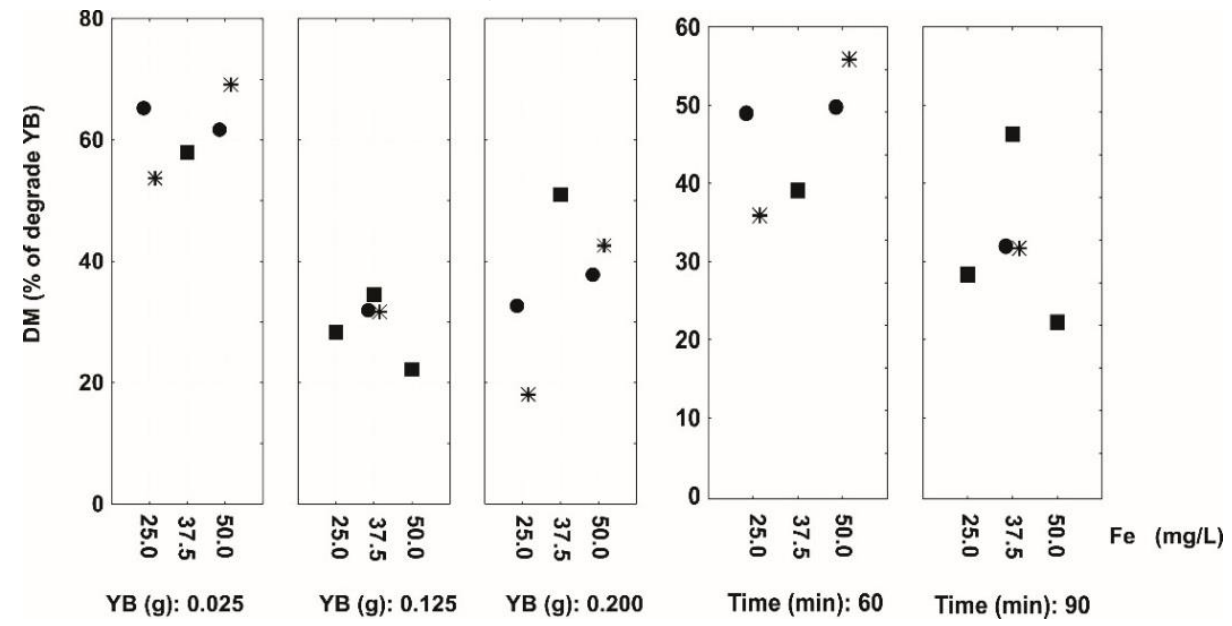

B) Total Organic Carbon (TOC)
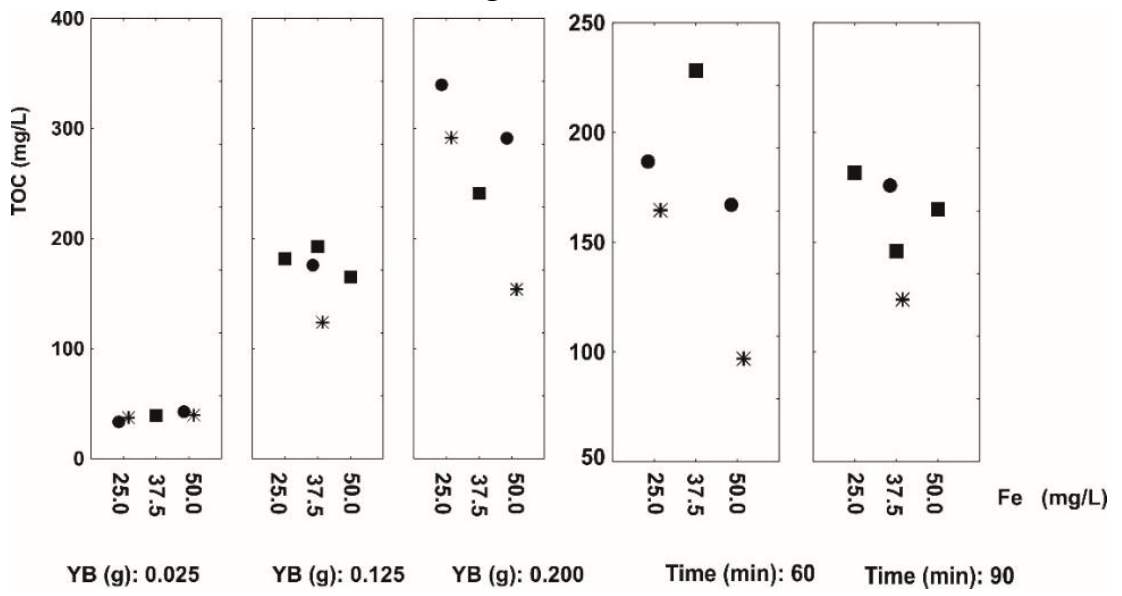

Figure 1. Graphics of marginal means for A) DM and B) TOC, considering the mass factor in their lower level of variation $(\mathrm{YB}=$ Yeast biomass fixed at $25 \mathrm{mg}$ ). $\bullet \mathrm{H}_{2} \mathrm{O}_{2}=5,000 \mathrm{mg} \mathrm{L} \mathrm{L}^{-1} ; \boldsymbol{\square}=\mathrm{H}_{2} \mathrm{O}_{2}=7,500 \mathrm{mg} \mathrm{L} \mathrm{L}^{-1}$; $*=\mathrm{H}_{2} \mathrm{O}_{2}=10,000 \mathrm{mg} \mathrm{L}^{-1}$.

In the search for the optimal conditions, we constructed degradation response surfaces for DM and TOC with the optimum fit, considering all the factors involved (Figure 2). For response surface graphs for DM and TOC, it appears that the best response for DM was obtained with $\mathrm{H}_{2} \mathrm{O}_{2}$ at the highest level and $\mathrm{Fe}^{2+}$ at an intermediate level. It was found that there is a dependency between $\mathrm{Fe}^{2+}$ and $\mathrm{H}_{2} \mathrm{O}_{2}$, since both are limiting reagents to produce $\cdot \mathrm{OH}$. For TOC, both situations, i.e. low and high concentrations of $\mathrm{Fe}^{2+}$ and $\mathrm{H}_{2} \mathrm{O}_{2}$, led to better responses, with lower TOC values.

The projection of the optimal point indicates that mass degradation (DM) was more efficient with high concentrations of $\mathrm{H}_{2} \mathrm{O}_{2}$ and $\mathrm{Fe}^{2+}$ (Figure 3). Considering the mass factor, both lower and in the higher concentrations of $\mathrm{H}_{2} \mathrm{O}_{2}$ and $\mathrm{Fe}^{2+}$ presented similar DM results, with a slight increase and a positive trend with higher concentrations of these reagents. The square profile of the response surface for the $\mathrm{Fe} \times \mathrm{YB}$ suggests the influence of other factors on $\mathrm{Fe}^{2+}$ behavior, probably peroxide. In other words, in a heterogeneous system, there is a need 
to properly set the stoichiometry of the reactants to allow for synergy between $\mathrm{H}_{2} \mathrm{O}_{2}$ and $\mathrm{Fe}^{2+}$ and achieve the degradation of the solid residue. The behavior was similar for both time points (60 and $90 \mathrm{~min}$ ).

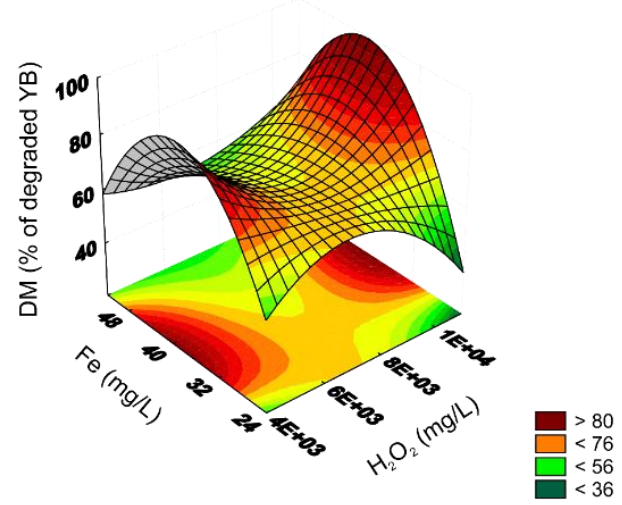

$D M=-1.1 E+03+3.3 E-01 x-2.3 E-05 x^{2}+6.8 E+01 y-8.5 E-01 y^{2}-1.8 E-02 x y+$ $2 E-04 x y^{2}+1.2 E-06 x^{2} y-1.5 E-08 x^{2} y^{2}+3.1 E-01(2.5 E-02 x)-2.1 E-05(2.5 E-1$ $\left.x^{2}\right)+2.0(2.5 E-02 y)-6.6 E+01$
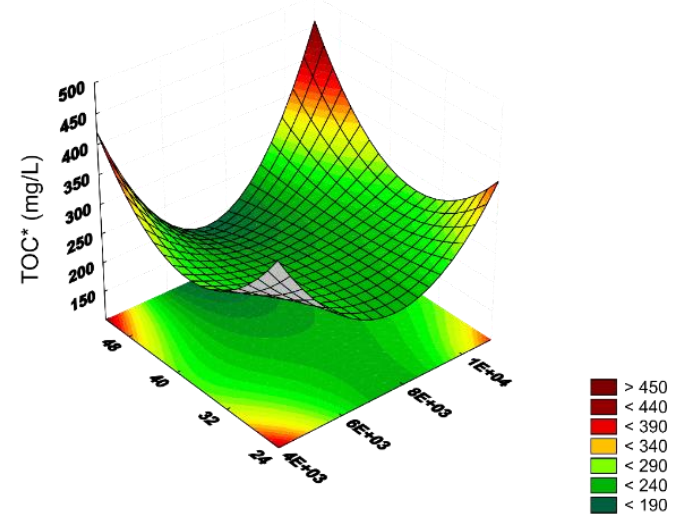
$0.56 E-08 x^{2} y^{2}+5.07 E-01(1.19 E-01 x)-2.67 E-05\left(1.19 E-01 x^{2}\right)+2.26 E+01(1.19 E-01 y)-3.41 E+02$
0

Figure 2. Surface responses for DM e TOC obtained from results obtained from experimental results of yeast biomass (YB) degraded by Fenton reaction according experimental design, 3 factors, 3 levels, 2 blocks, 20 experiments. Mass at minor level and $\mathrm{t}=60$ min. Subtitle: $\mathrm{P}=\mathrm{H}_{2} \mathrm{O}_{2}, \mathrm{Fe}=\mathrm{Fe}^{2+}$ and $\mathrm{YB}$ (mass of yeast biomass). For display purposes, the TOC matrix had their numerical values inverted so that the regions in red correspond to lower TOC values.

As for TOC (Figure 4), the determining factor for lower values was peroxide, suggesting that the homogeneous reaction process with the highest concentration of peroxide contributed to the attack of $\bullet \mathrm{OH}$ free radicals on solubilized fragments of YB.
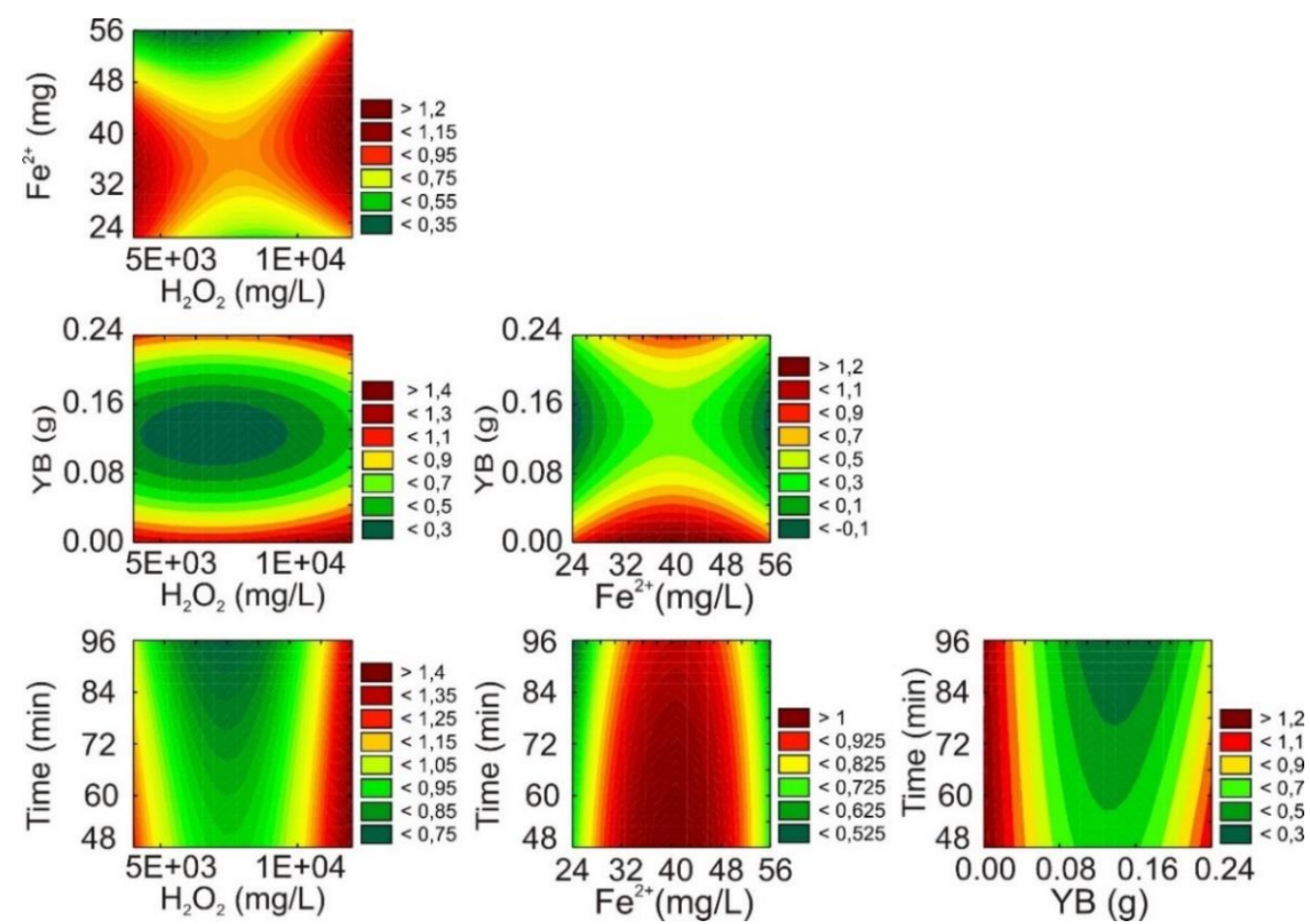

Figure 3. Surface responses for mass degradation DM obtained from experimental results of yeast biomass (YB) degraded by Fenton reaction according experimental design, 3 factors, 3 levels, 2 blocks, 20 experiments. Where: $\mathrm{Fe}=\mathrm{Fe}^{2+}, \mathrm{YB}=$ mass of yeast biomass). 

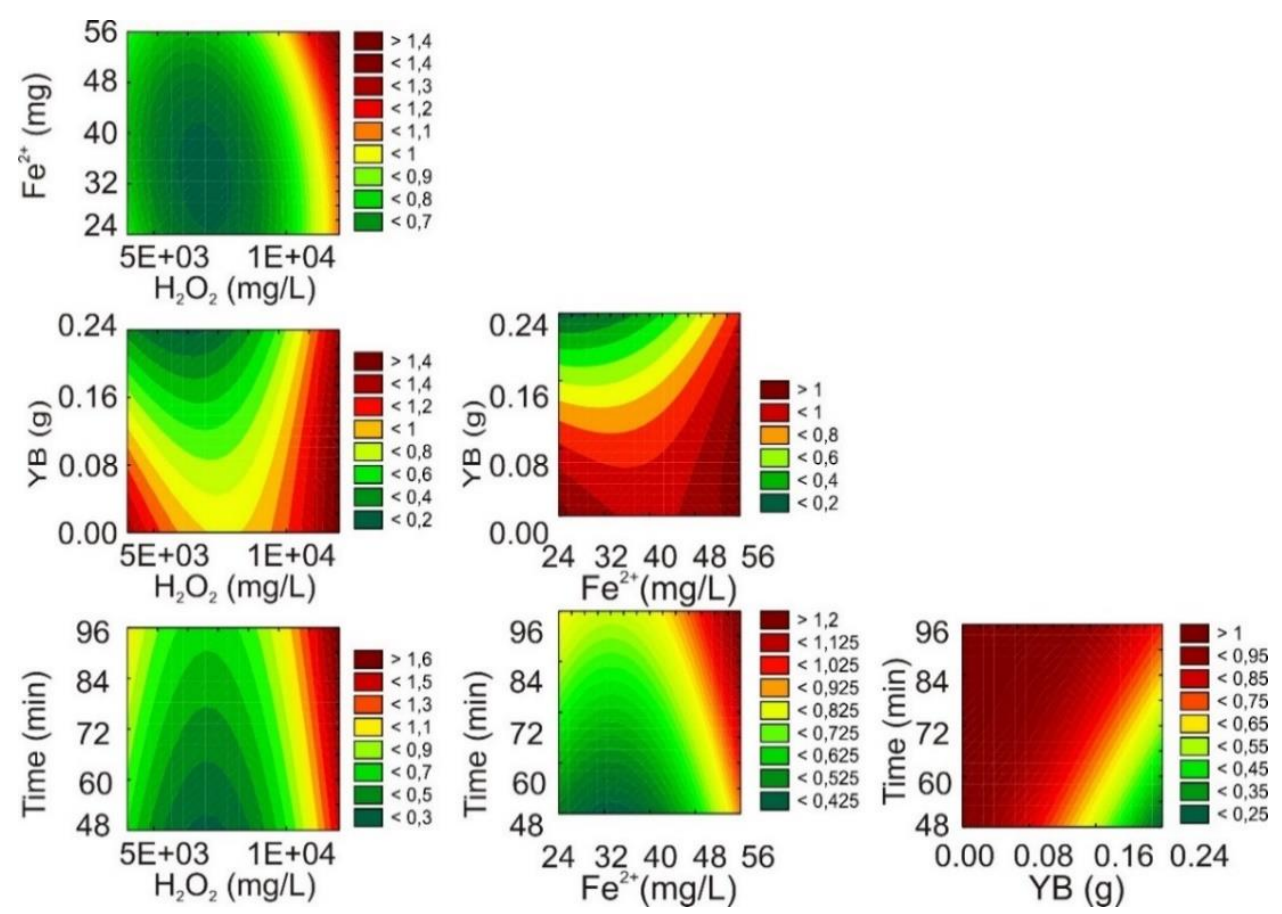

Figure 4. Surface responses for total organic carbon (TOC) obtained from experimental results of yeast biomass (YB) degraded by Fenton reaction according experimental design, 3 factors, 3 levels, 2 blocks, 20 experiments. Where: $\mathrm{Fe}=$ $\mathrm{Fe}^{2+}, \mathrm{YB}=$ mass of yeast biomass). *For display purposes, the TOC matrix had their numerical values inverted so that the regions in red correspond to lower TOC values which were converted by the equation $|(y m a ́ x-y i)(x)|=f(x)$ to make the interpretation simpler.

It is interesting to note that the behavior of the degradation kinetics was reversed for DM and TOC; in other words, less time led to better DM while longer times led to lower TOC. It is likely that the free radicals generated at the start of the Fenton process preferably attacked the organic matter available at this time point in the solid residue. Over time, as previously discussed, the consumption of reagents and the formation of $\mathrm{Fe}^{3+}$ led to the formation of weaker free radical attack, preferentially on the solubilized fractions (Rig et al., 1954; Walling and Goosen, 1973).

\subsection{Prediction of the best Fenton degradation conditions}

In order to establish a mathematical model that describes the experimental behavior and to optimize the results in order to reduce experimental errors for predicting the maximum performance possible, the conditions for DM and TOC were simultaneously assessed by multivariate calibration using MARS.

Since the values of DM and TOC (Table 2) obtained experimentally did not reproduce the predictions obtained by MARS using all points of the lines of observed $\times$ predicted values shown in Figure 5A, strategies were established to minimize the effect of the mass factor on the response. These strategies consisted of applying MARS to two different sets of data: 1) the data set that was less influenced by the mass factor in terms of the response (E1), thereby reducing the effect of the mass factor to a minimum (highlighted by the ellipse in Figure 5) and 2) the data that showed the best linear fit extracted from the full set of the results in Figure 5A (E2).

Calibration by this regression model was chosen because this modeling fits very well to non-parametric data (Friedman, 1991). Analysis by PLS determined the order of importance of the variables (continuous predictors) relative to DM and TOC (dependent variables), considering the linear range of data used in MARS, as shown in Figure 5A. 
A) Predicted $\times$ observed values
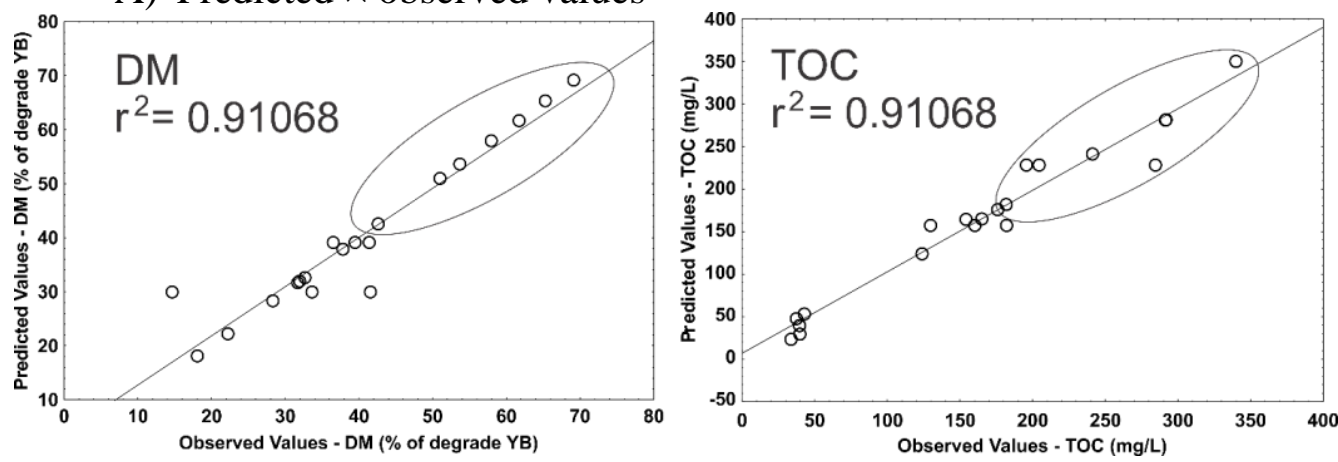

B) Pareto's diagrams
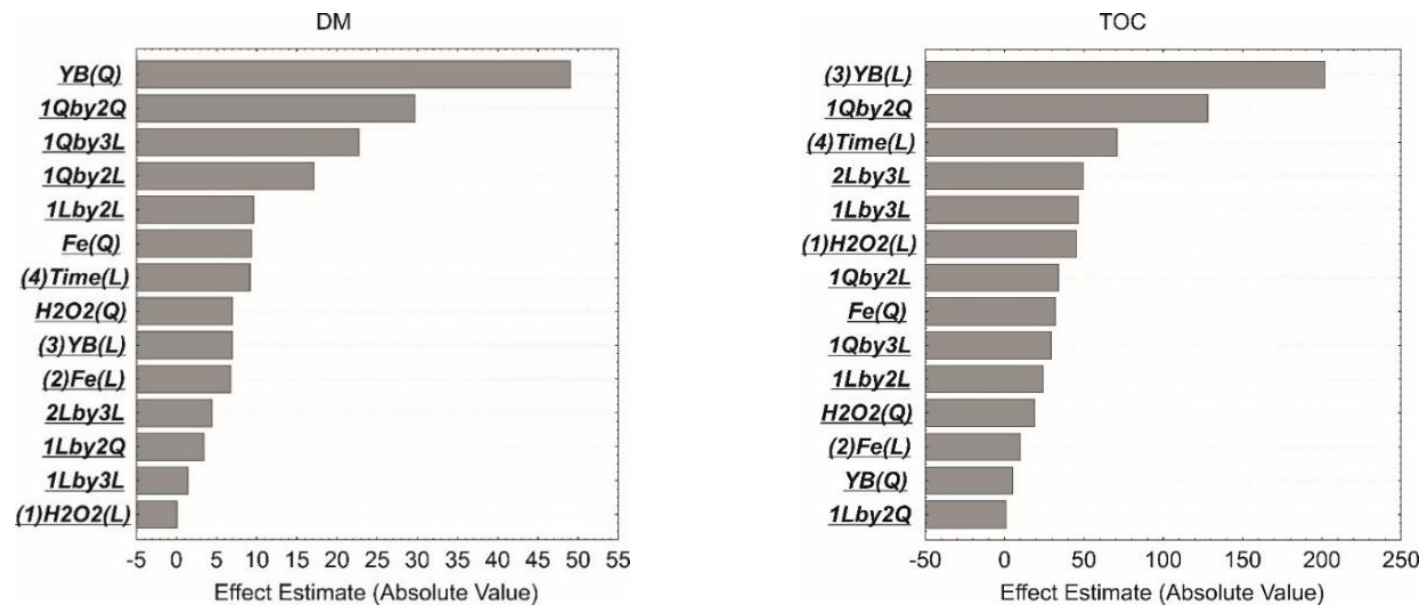

Figure 5. A) Predicted $\times$ observed values and B) Pareto's diagrams for data obtained by experimental design considering degraded mass (DM) and TOC reduction.

When considering the complete experimental matrix and the PLS loading chart in the loading scatter plot (Figure 6), it can be observed that the YB parameter shows a more pronounced contribution in comparison with the others (time, $\mathrm{H} 2 \mathrm{O} 2$, and Fe). The diverse phenomena involved in processes such as degradation (as an example, chemical interactions between the employed reagents, molecular bond breaking and the formation of new substances) require a more sensitive mathematical model that allows for the perception of nuances in complex data.

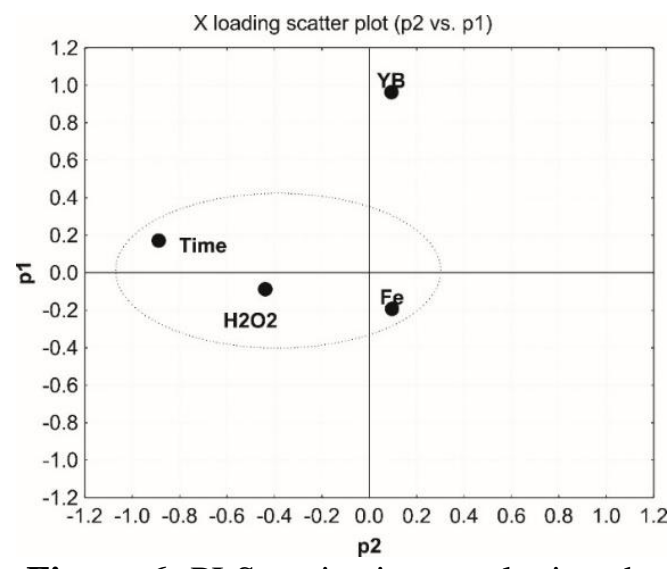

Figure 6. PLS projection employing the all experimental data of DM and TOC obtained from conduction of experimental design. 
Table 2. Comparison of experimental $\times$ predicted values obtained employing the different modeling strategies: A) MARS using the points of the linear range highlighted on Figure 5A (E1), B) MARS using data with best linear fit of the complete data employed to construct the Figure 5A (E2) and C) Employing the experimental design. Condition I: 8,000 mg L-1 de $\mathrm{H}_{2} \mathrm{O}_{2}+40 \mathrm{mg} \mathrm{L}^{-1}$ de Fe $\mathrm{Fe}^{2+}, 60 \mathrm{~min}$ e $25 \mathrm{mg}$ de YB; Condition II: 10,000 mg L $\mathrm{L}^{-1} \mathrm{de} \mathrm{H}_{2} \mathrm{O}_{2}+50 \mathrm{mg} \mathrm{L}^{-1}$ de $\mathrm{Fe}^{2+}, 60 \mathrm{~min}$ e $25 \mathrm{mg}$ de $\mathrm{YB}$.

\section{Condition I}

\begin{tabular}{|c|c|c|c|c|c|c|c|c|c|c|}
\hline \multirow[t]{2}{*}{ Modeling } & \multicolumn{2}{|c|}{ Predicted } & \multicolumn{2}{|c|}{$\begin{array}{c}\text { Obtained } \\
\text { Experimentally }\end{array}$} & \multirow[t]{2}{*}{$\begin{array}{l}\text { Relative error } \\
\text { for DM }(\%)\end{array}$} & \multicolumn{2}{|c|}{ Predicted } & \multicolumn{2}{|c|}{$\begin{array}{c}\text { Obtained } \\
\text { Experimentally }\end{array}$} & \multirow[t]{2}{*}{$\begin{array}{c}\text { Relative error for } \\
\text { DM }(\%)\end{array}$} \\
\hline & $\begin{array}{c}\text { TOC } \\
\left(\mathrm{mg} \mathrm{L}^{-1}\right)\end{array}$ & $\begin{array}{l}\mathrm{DM} \\
(\%)\end{array}$ & $\begin{array}{c}\text { TOC } \\
\left(\mathrm{mg} \mathrm{L}^{-1}\right)\end{array}$ & $\begin{array}{l}\mathrm{DM} \\
(\%)\end{array}$ & & $\begin{array}{c}\text { TOC } \\
\left(\mathrm{mg} \mathrm{L}^{-1}\right)\end{array}$ & $\begin{array}{l}\text { DM } \\
(\%)\end{array}$ & $\begin{array}{c}\text { TOC } \\
\left(\mathrm{mg} \mathrm{L}^{-1}\right)\end{array}$ & $\begin{array}{l}\mathrm{DM} \\
(\%)\end{array}$ & \\
\hline $\mathrm{A}(\mathrm{E} 1)$ & 38.63 & 63.95 & & & 2.5 & 39.75 & 69.12 & & & $9.7(1.8)^{1}$ \\
\hline B (E2) & 39.01 & 62.56 & $43 \pm 3$ & $62 \pm 2$ & 0.9 & 39.97 & 68.22 & $45 \pm 5$ & $63 \pm 5$ & $8.3(0.35)^{1}$ \\
\hline $\mathrm{C}$ & 113.5 & 66.77 & & & 7.7 & 29.5 & 69.17 & & & 9.8 \\
\hline
\end{tabular}

\section{Condition II}

${ }^{1}$ in parentheses are shown the errors for the theoretical models considering the comparison of the predicted values and the experimental values with their confidence intervals. 
By analyzing the effect of the $\mathrm{H}_{2} \mathrm{O}_{2}$ concentration at the extreme limits, the increase of this factor from the lowest level to the highest $\mathrm{YB}$ reduced the degradation efficiency. This decrease can be explained by the fact that the excess $\mathrm{H}_{2} \mathrm{O}_{2}$ in the reaction medium $\left(>10,000 \mathrm{mg} \mathrm{L}^{-1} \mathrm{H}_{2} \mathrm{O}_{2}\right)$ gives the best oxidation results with $\mathrm{Fe}^{3+}$ ions in the medium instead of $\mathrm{Fe}^{2+}$ ions. An excess of $\mathrm{H}_{2} \mathrm{O}_{2}$ also favors the self-decomposition of this reagent and hydroxyl radical sequestration reactions, generating radicals with lower oxidizing power, as shown in Equation 1 (Rigg et al., 1954; Walling and Goosen, 1973; Buxton et al., 1988).

$$
\mathrm{H}_{2} \mathrm{O}_{2}+\cdot \mathrm{OH} \rightarrow \mathrm{HO}_{2} \bullet+\mathrm{H}_{2} \mathrm{O} \mathrm{k} 8=2.7 \times 10^{7} \mathrm{M}^{-1} \mathrm{~s}^{-1}
$$

An increase in the $\mathrm{Fe}^{2+}$ concentration increases the speed of the Fenton reaction, causing the $\mathrm{H}_{2} \mathrm{O}_{2}$ concentration to decrease rapidly and minimizing the sequestration of $\bullet \mathrm{OH}$ (Villa et al., 2007). On the other hand, the increase in reaction speed contributes to the formation of a greater amount of $\mathrm{Fe}^{3+}$ ions, which react with $\mathrm{H}_{2} \mathrm{O}_{2}$ and generate weaker radicals. This decreases the speed of the reaction and has an impact on the efficiency of the reaction, according to Equation 2 and 3 (Rigg et al., 1954; Walling and Goosen, 1973; Buxton et al., 1988).

$$
\begin{aligned}
& \mathrm{Fe}^{3+}+\mathrm{H}_{2} \mathrm{O}_{2} \rightarrow \mathrm{FeOOH}^{2+}+\mathrm{H}^{+} \mathrm{k} 11=0.001-0.01 \mathrm{M}^{-1} \mathrm{~s}^{-1} \\
& \mathrm{Fe}^{3+}+\mathrm{HO}_{2} \bullet \mathrm{Fe}^{2+}+\mathrm{O}_{2}+\mathrm{H}^{+} \mathrm{k}_{14}=1.2 \times 10^{6} \mathrm{M}^{-1} \mathrm{~s}^{-1}
\end{aligned}
$$

In this case, two dependent variables (DM and TOC) and other planning factors (Fe, $\mathrm{P}, \mathrm{M}$ and $\mathrm{T}$ ) were taken as continuous predictors. The Equation 4 describes the general model where $\mathrm{M}$ is a non-constant term, $\beta_{0}$ is the intercept parameter and $\beta_{m}$ is a weighting factor for $h_{m}(X)$ basic functions.

$$
y=f(X)=\beta_{0}+\sum_{m-1}^{M} \beta_{m} h_{m}(X)
$$

Simulation by an automated neural network (model regression) corroborated the results obtained by MARS, but the determination coefficient was lower (0.897 vs. 0.998).

The optimization results were validated experimentally by comparing the real results obtained in the Fenton experiments with the theoretical results calculated by the proposed model, as shown in Table 2. The regression model responded appropriately with an error between 2.5 and $9 \%$ for the set of E1 data, which was not observed when the complete matrix of experimental data was used. The process was optimized since it was possible to describe a linear regression model that could be reproduced experimentally.

When comparing the experimental value obtained using the best conditions predicted by MARS (BM), namely 8,000 $\mathrm{mg} \mathrm{L}^{-1} \mathrm{H}_{2} \mathrm{O}_{2}$ and $40 \mathrm{mg} \mathrm{L}^{-1} \mathrm{Fe}^{2+}$, with the theoretical value obtained by linear regression, it was possible to observe a relative error of only $2.5 \% \mathrm{DM}$. This error is perfectly acceptable since we were working with a heterogeneous matrix, which decreased the reproducibility of the results.

After the experimental validation of the results, we continued our studies using the following conditions to degrade YB: A) the best experimental conditions (BE) with $10,000 \mathrm{mg}$ $\mathrm{L}^{-1} \mathrm{H}_{2} \mathrm{O}_{2}$ and $50 \mathrm{mg} \mathrm{L}^{-1} \mathrm{Fe}^{2+}$ and $\mathrm{B}$ ) the best conditions predicted by MARS (BM) with 8,000 $\mathrm{mg} \mathrm{L}^{-1} \mathrm{H}_{2} \mathrm{O}_{2}$ and $40 \mathrm{mg} \mathrm{L}^{-1} \mathrm{Fe}^{2+}$. Both were performed for $60 \mathrm{~min}$ at $\mathrm{pH} 3$; the obtained DM and TOC values are presented in Table 3 . These conditions were also used for the experiments employing UV radiation, with the results shown in Table 3. 
Table 3. Results of Degraded Mass (DM) and TOC obtained with UV irradiation (30W and 80W) and the best Fenton conditions $(\mathrm{N}=6)$.

\begin{tabular}{lccccc}
\hline & \multicolumn{3}{c}{ Parameter } & \multicolumn{2}{c}{ Answer } \\
\cline { 2 - 6 } & $\begin{array}{c}\mathrm{H}_{2} \mathrm{O}_{2} \\
\left(\mathrm{mg} \mathrm{L}^{-1}\right)\end{array}$ & $\begin{array}{c}\mathrm{Fe}^{2+} \\
\left(\mathrm{mg} \mathrm{L}^{-1}\right)\end{array}$ & $\begin{array}{c}\text { YB } \\
(\mathrm{mg})\end{array}$ & $\begin{array}{c}\mathrm{TOC} \\
\left(\mathrm{mg} \mathrm{L}^{-1}\right)\end{array}$ & $\begin{array}{c}\mathrm{DM} \\
(\%)\end{array}$ \\
\hline Best MARS (BM) & 8,000 & 40 & 25 & $43 \pm 3$ & $63 \pm 2$ \\
Best MARS 30 W (BM-30W) & 8,000 & 40 & 25 & $30 \pm 2$ & $72 \pm 2$ \\
Best Experimental (BE) & 10,000 & 50 & 25 & $29 \pm 5$ & $62 \pm 4$ \\
Best Experimental 30 W (BE-30W) & 10,000 & 50 & 25 & $28 \pm 1$ & $70 \pm 4$ \\
Best Experimental 80 W (BE-80W) & 10,000 & 50 & 25 & $29 \pm 1$ & $72 \pm 2$ \\
\hline
\end{tabular}

\subsection{Application of ultraviolet radiation to the best Fenton degradation conditions}

Further experiments were performed in triplicate under the same conditions as the experiments conducted with the Fenton reaction. However, germicidal lamps of 30 and $80 \mathrm{~W}$ were used during the process; the results are shown in Table 4.

It can be seen that UV radiation caused an increase in YB degradation of up to $12 \%$, which was expected since the effect of UV radiation in advanced oxidation processes promotes the reduction of $\mathrm{Fe}^{3+}$ to $\mathrm{Fe}^{2+}$. This occurs by promoting an electron from an orbital centered on the binder to an orbital centered on the metal. In the case of $\mathrm{Fe}^{3+}$, the ligand-metal charge transfer is shown in Equation 5 (Langford and Carey, 1975).

$$
\mathrm{Fe}(\mathrm{OH})^{2+}+\mathrm{h} v \rightarrow \mathrm{Fe}^{2+}+\cdot \mathrm{OH}
$$

As seen in Equation 5, $\mathrm{Fe}^{2+}$ is regenerated by $\mathrm{UV}$ radiation, process by which $\cdot \mathrm{OH}$ radicals are also formed. The regeneration of the reactional medium allows the continuation of the oxidation process.

The comparison between the averages of all treatments was performed using analysis of variance (ANOVA), followed by the Tukey test for the detection of differences at $\alpha=0.05$. The ANOVA indicated that the averages were significantly different $(\mathrm{p}<0.05)$, and the Tukey test indicated that the Fenton treatments differed from the UV treatments $(p<0.05)$. However, the Fenton treatments did not differ, and the UV treatments did not differ (Table 4), corroborating the conclusion that the best conditions predicted by MARS (BM) provided the same degradation results as the best conditions obtained experimentally (BE), strengthening the descriptive character of the mathematical model applied in relation to the experimental data.

Table 4. $Q$ values (lower diagonal) and $p$ values (upper diagonal with significant values in bold) from Tukey test from the different Fenton treatments. $\mathrm{BE}=$ Best Experimental design, $\mathrm{BM}=$ Best Mars.

\begin{tabular}{lccccc}
\hline & BM & BE & BM 30W & BE 30W & BE 80W \\
\hline Best MARS & - & 0.9243 & 0.0036 & 0.0456 & 0.0032 \\
BE & 1.540 & - & 0.0004 & 0.0044 & 0.0004 \\
BM 30W & 6.365 & 7.905 & - & 0.8909 & 1.0000 \\
BE 30W & 4.686 & 6.225 & 1.679 & - & 0.8731 \\
BE 80W & 6.429 & 7.969 & 0.064 & 1.744 & - \\
\hline
\end{tabular}


By increasing the power of the lamp from $30 \mathrm{~W}$ to $80 \mathrm{~W}$, as shown by the results presented in Table 4, there was no gain in the case where the same conditions and reagents were employed (BE, BE $30 \mathrm{~W}$; BM and BM 30 and $80 \mathrm{~W}$ ); thus, increasing the lamp power did not increase YB degradation.

In addition, as seen in Tables 3 and 4, the results found for DM when employing degradation conditions by MARS (BM) and the experimental design (BE) were statistically similar, as well as the results found for samples degraded by UV radiation. Therefore, it is possible to see that for the degradation of YB by UV-Fenton the reagents concentration did not contribute to the process yield. On the other hand, the DM results for procedures with or without UV radiation were statistically different.

These results led to the conclusion that the use of milder conditions and lower energy consumption are satisfactory for the degradation of YB. Thus, it was established that the best conditions for photo-Fenton degradation were: 8,000 $\mathrm{mg} \mathrm{L}^{-1} \mathrm{H}_{2} \mathrm{O}_{2}$ and $40 \mathrm{mg} \mathrm{L}^{-1} \mathrm{Fe}^{2+}, \mathrm{pH} \mathrm{3}$, time $60 \mathrm{~min}$, with $25 \mathrm{mg}$ of $\mathrm{YB}$, and a $30 \mathrm{~W}$ power UV lamp.

\subsection{Characterization of $Y B$ after Fenton degradation}

After YB degradation using the Fenton process, the residue was taken for analysis by scanning electron microscopy (SEM) to compare YB and the degraded waste, as shown in Figure 6. The images in Figure 6 show that degradation into the photo-Fenton residue (PF) changed the physical characteristics of YB. It was possible to complete the Fenton degradation process by breaking the YB cell wall structure into smaller particles, thus allowing the solubilization and digestion of the residue.

The elemental analyses for $\mathrm{YB}$ and the degradation residues from the Fenton (FR) and photo-Fenton 30W (PF) degradations employing 8,000 mg L ${ }^{-1} \mathrm{H}_{2} \mathrm{O}_{2}, 40 \mathrm{mg} \mathrm{L}^{-1} \mathrm{Fe}^{2+}, 60 \mathrm{~min}$, $25 \mathrm{mg}$ of $\mathrm{YB}$ and $\mathrm{pH} 3$, presented:

a) YB: $\mathrm{C}=40.6 \%, \mathrm{H} 7.3 \%, \mathrm{~N}=6.1 \%, \mathrm{~S}=0.2 \%$;

b) FR: $\mathrm{C}=23.3 \%, \mathrm{H} 3.8 \%, \mathrm{~N}=9.7 \%, \mathrm{~S}=0.7 \%$; and

c) PF: $\mathrm{C}=19.8 \%, \mathrm{H} 5.7 \%, \mathrm{~N}=6.3 \%, \mathrm{~S}=0.7 \%$.

These results show a change in the composition of the remaining solid organic material, with a considerable reduction in the carbon contribution to the elemental composition of the samples, which corroborates the finding that effectively applied AOPs promote the degradation of the biosorbent and can be potentially applied for the remediation of solid waste generated after sorption.

The infrared spectra (Figure 7) are in accordance with the elemental analysis results, which denoted different organic compositions of YB, FR, and PF. The peaks $1026-1029 \mathrm{~cm}^{-1}$ were attributed to $v(\mathrm{C}-\mathrm{O}-\mathrm{C})$ - polysaccharides or $v(\mathrm{C}-\mathrm{O})$, which are not found in the PF residue spectra (Labuto et al., 2015). For the FR, it is possible to observe the band at $1723 \mathrm{~cm}^{-1}$, indicating the presence of lipids and fatty acids $v(C=O)$ - ester (Shi et al., 2010). According to Shi et al. (2010) this is due to the depletion of the highly dense structure of the cell walls. The most noticeable feature is the strong intensity of the band at $1026 \mathrm{~cm}^{-1}$, assignable to $v(\mathrm{C}-\mathrm{O}-\mathrm{C})$ -polysaccharides or $v(\mathrm{C}-\mathrm{O})$, indicating similarity with YB. The PF shows a slight shift in the amide (I) band, and an increased absorption, indicating a change in the protein structure. A new band appearing at $1725 \mathrm{~cm}^{-1}$ was assigned to ester groups from lipids and fatty acids. A strong band at ca. $1342 \mathrm{~cm}^{-1}$ also develops, and some new bands appear at 1149, 1107, 1077 and $829 \mathrm{~cm}^{-1}$, this last one assigned to "exposed" tyrosine (Maquelin et al., 2002). 


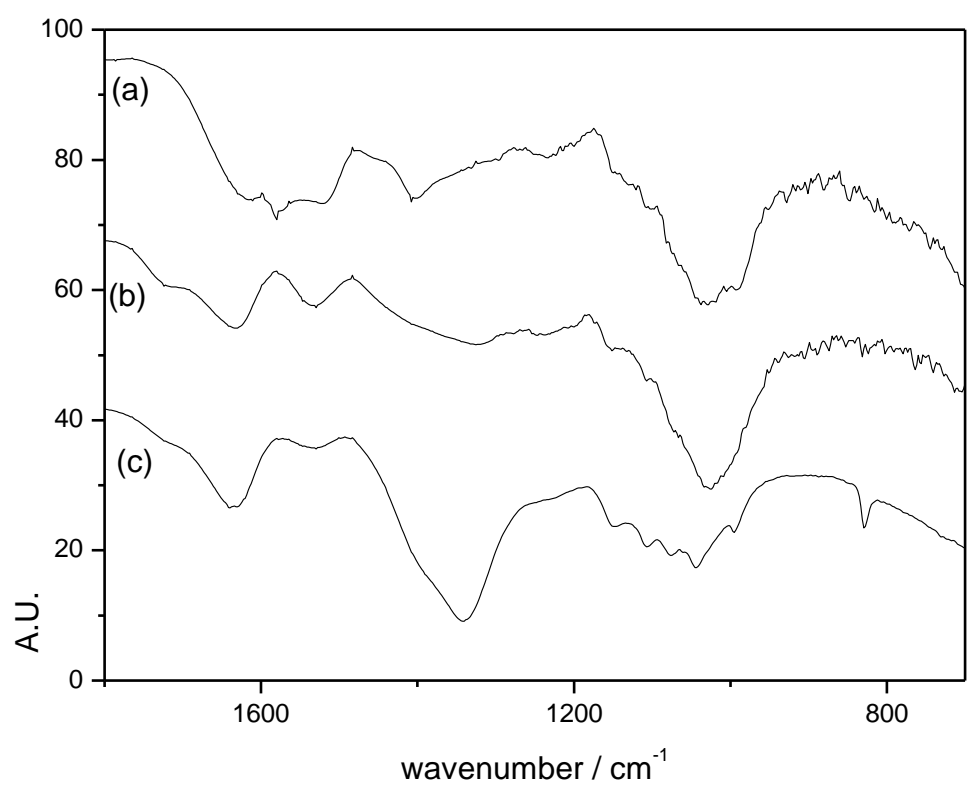

Figure 7. Fourier Infrared spectra presenting the main functional groups for a) Yeast Biomass (YB); b) Fenton Residue (FR) and, c) photo Fenton residue (PF). Resolution: $4 \mathrm{~cm}^{-1}$ at 20 scans $\mathrm{min}^{-1}$.

\section{CONCLUSIONS}

The degradation of organic solids by Fenton and photo-Fenton oxidative degradation processes is feasible and can be a viable alternative to treating biosorbents after the sorption of organic and inorganic contaminants. In case of Yeast Biomass, it was possible to degrade around $72 \%$ of the solid to soluble compounds (the best conditions for photo-Fenton degradation were: $8,000 \mathrm{mg} \mathrm{L}^{-1} \mathrm{H}_{2} \mathrm{O}_{2}$ and $40 \mathrm{mg} \mathrm{L}^{-1} \mathrm{Fe}^{2+}$, $\mathrm{pH} \mathrm{3}$, time $60 \mathrm{~min}$, with $25 \mathrm{mg}$ of $\mathrm{YB}$, and a $30 \mathrm{~W}$ power UV lamp). It is important to note that the allocation of the final solid waste and the solubilized organic fraction from oxidative degradation will also depend on their toxicity, which is directly related to the adsorbed chemical species and the final products of degradation. However, the considerable reduction in the solid waste promoted by the proposal oxidative process minimizes the impact on the disposal of solid residue after its use as biosorbent.

\section{ACKNOWLEDGMENTS}

This study was financially supported by CNPq (fellowship) and FAPESP (grant 2007/53860-6 and 2016/06271-4). The authors are grateful to Hermes Dias Brito from Centro de Geociências Aplicadas ao Petróleo - UNESPetro. Universidade Estatual Paulista. Rio Claro for obtaining the SEM images.

\section{REFERENCES}

AMIRI, A.; SABOUR, M. R. Multi-response optimization of Fenton process for applicability assessment in landfill leachate treatment. Waste Management, v. 34, p. 2528-2536, 2014. https://doi.org/10.1016/j.wasman.2014.08.010 
BHANGE, V. P.; WILLIAM, S. P. M. P.; SHARMA, A.; GABHANE, J.; VAIDYA, A. N.; WATE, S. R. Pretreatment of garden biomass using Fenton's reagent: influence of $\mathrm{Fe}^{2+}$ and $\mathrm{H}_{2} \mathrm{O}_{2}$ concentrations on lignocellulose degradation. Journal of Environmental $\begin{array}{lllllll}\text { Health Science } \quad \text { \& } & \text { Engineering, } & \text { v. 13, }\end{array}$ https://doi.org/10.1186/s40201-015-0167-1

BUXTON, G. V.; GREENSTOCK, C. L.; HELMAN, W. P.; ROSS, A. B. Critical review of rate constants for reactions of hydrated electrons, hydrogen atoms and hydroxyl radicals $\left(\mathrm{OH} / \mathrm{O}^{-}\right)$in aqueous solution. Journal of Physical and Chemical Reference Data, v. 17, p. 513, 1988. http://dx.doi.org/10.1063/1.555805

CORTEZ, S.; TEIXEIRA. P.; OLIVEIRA, R.; MOTA, M. Evaluation of Fenton and ozonebased advanced oxidation processes as mature landfill leachate pre-treatments. Journal

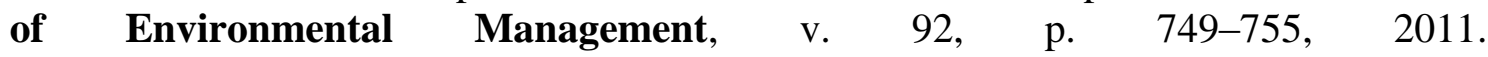
https://doi.org/10.1016/j. jenvman.2010.10.035

FERREIRA, I. V.; DANIEL, L. A. Fotocatálise heterogênea com $\mathrm{TiO}_{2}$ aplicada ao tratamento de esgoto sanitário secundário. Engenharia Sanitária e Ambiental, v. 9, p. 335-342, 2004. http://dx.doi.org/10.1590/S1413-41522004000400011

FRIEDMAN, J. H. Multivariate adaptive regression splines. The Annals of Statistics, v. 19, p. 1-67, 1991. http://www.jstor.org/stable/2241837

GIRARDI, F.; CICHELlI, A.; PERRI, E.; BASTI, C.; D'ALESSANDRO, N. Oxidative treatments of solid olive residues: Effects on phenolic and fatty acid fractions. European Journal of Lipid Science and Technology, v. 116, p. 352-359, 2014. http://dx.doi.org/10.1002/ejlt.201300083

GUERRERO, L. A.; MAAS, G.; HOGLAND, W. Solid waste management challenges for cities in developing countries. Waste Management, v. 33, p. 220-232, 2013. https://doi.org/10.1016/j.wasman.2012.09.008

HE, R.; TIAN, B-H.; ZHANG, Q. Q.; ZHANG, H-T. Effect of Fenton oxidation on biodegradability, biotoxicity and dissolved organic matter distribution of concentrated landfill leachate derived from a membrane process. Waste Management, v. 38, p. 232239, 2015. https://doi.org/10.1016/j.wasman.2015.01.006

KLAMERTH, N.; MALATO, S.; AGÜERA, A.; FERNÁNDEZ-ALBA, A. Photo-Fenton and modified photo-Fenton at neutral $\mathrm{pH}$ for the treatment of emerging contaminants in wastewater treatment plant effluents: a comparison. Water Research, v. 47, p. 833-40, 2013. https://doi.org/10.1016/j.watres.2012.11.008

LABUTO, G.; TRAMA, B.; SILVEIRA, G. C.; GUARNIERI, B. S.; SILVA, F. V.; COLAZZO, R. Metals uptake by live yeast and heat-modified yeast residue. Revista Ambiente \& Água, v. 10, p. 510-519, 2015. http://dx.doi.org/10.4136/ambi-agua. 1577

LABUTO, G.; CARRILHO, E. N. V. M. Bioremediation in Brazil: Challenges to improve the development and application to boost up the bioeconomy. In: PRASAD, M. N. V. (Ed.). Bioremediation and Bioeconomy. Oxford: Elsevier, 2016. p. 569-586.

LANGFORD, C. H.; CAREY, J. H. The charge transfer photochemistry of the hexaaquoiron (III) ion, the chloropentaaquoiron (11l) ion, and the $\mu$-dihydroxo dimer explored with tertbutyl alcohol scavenging. Canadian Journal of Chemistry, v. 43, p. 2430-2435, 1975. https://doi.org/10.1139/v75-344 
LI, W.; ZHOU. O.; HUA, T. Removal of organic matter from landfill leachate by advanced oxidation processes: a review. International Journal of Chemical Engineering, v. 2010, p. 1-10, 2010. http://dx.doi.org/10.1155/2010/270532

LI, J.; ZHAO, L.; QIN, L.; TIAN, X.; WANG, A.; ZHOUA, Y. et al. Removal of refractory organics in nanofiltration concentrates of municipal solid waste leachate treatment plants by combined Fenton oxidative-coagulation with photo - Fenton processes. $\begin{array}{lllll}\text { Chemosphere, } & \text { v. } & 146, & \text { p. } & 442-449,\end{array}$ https://doi.org/10.1016/j.chemosphere. 2015.12.069

MACKLIN, Y.; KIBBLE, A.; POLLITT, F. Impact on health of emissions of landfield sites, Advice of Health Protection Agency, Radiation. London: Chilton, Didcot, Oxfordshire: Health Protection Agency; Centre for Radiation, Chemical and Environmental Hazards, 2011. (Documents of the Health Protection Agency. Radiation, chemical and environmental hazards; RCE-18).

MAHMAD, F.; YOUNESI, H.; BAHRAMIFAR, N.; HADAVIFAR, M. Optimization of Fenton and Photo-fenton-based Advanced Oxidation Processes for Post-treatment of Composting Leachate of Municipal Solid Waste by an Activated Sludge Process. KSCE Journal of Civil Engineering, v. 20, p. 2177-2188, 2016. https://doi.org/10.1007/s 12205-015-1045-1

MAQUELIN, K.; KIRSCHNER, C.; CHOO-SMITH, L. P.; VAN DEN BRAAK, N.; ENDTZ, H. P.; NAUMANN, D. et al. Identification of medically relevant microorganisms by vibrational spectroscopy. Journal of Microbiological Methods, v. 51, p. 255-71, 2002. https://doi.org/10.1016/S0167-7012(02)00127-6

MORAVIA, W. G.; AMARAL, M. C. S.; LANGE, L. C. Evaluation of landfill leachate treatment by advanced oxidative process by Fenton's reagent combined with membrane separation system. Waste Management, v. 33, p. 89-101, 2013. https://doi.org/10.1016/j.wasman.2012.08.009

NEYENS, E.; BAEYENS, J. A review of classic Fenton's peroxidation as an advanced oxidation technique. Journal of Hazardous Materials, v. 98, p. 33-50, 2003. https://doi.org/10.1016/S0304-3894(02)00282-0

NEYENS, E.; BAEYENS, J.; WEEMAES, M.; DE HEYDER, B. Advanced biosolids treatment using $\mathrm{H}_{2} \mathrm{O}_{2}$-oxidation. Environmental Engineering and Science, v. 19, p. 27-35, 2002. https://doi.org/10.1089/109287502753590214

PATERLINI, W. C.; NIGUEIRA, R. F. P. Multivariate analysis of photo-Fenton degradation of the herbicides tebuthiuron, diuron and 2, 4-D. Chemosphere, v. 58, p. 1107-1116, 2005. https://doi.org/10.1016/j.chemosphere.2004.09.068

PONTES, R. F. F.; MORAES, J. E. F.; MACHULEK JR., A.; PINTO, J. M. A mechanistic kinetic model for phenol degradation by the Fenton process. Journal of Hazardous Materials, v. 176, p. 402-413, 2010. https://doi.org/10.1016/j.jhazmat.2009.11.044

RENOU, S.; GIVAUDAN, J. G.; POULAIN, S.; DIRASSOUYAN, F.; MOULIN, P. Landfill leachate treatment: Review and opportunity. Journal of Hazardous Materials, v. 150, p. 468-493, 2008. https://doi.org/10.1016/j.jhazmat.2007.09.077 
RIGG, T.; TAYLOR, W.; WEISS, J. The rate constant of the reaction between hydrogen peroxide and ferrous ions. AIP The Journal of Chemical Physics, v. 22, p. 575-577, 1954. http://dx.doi.org/10.1063/1.1740127

SHI, G.; RAO, L.; XIE, Q.; LI, J.; LI, B.; XIONG, X. Characterization of yeast cells as a microencapsulation wall material by Fourier-transform infrared spectroscopy. $\begin{array}{llllll}\text { Vibrational Spectroscopy, } & \text { v. } & \text { 53, } & \text { p. }\end{array}$ https://doi.org/10.1016/j. vibspec.2010.04.007

SOLOZHENKO, E. G.; SOBOLEVA, N. M; GONCHARUK, V. V. Decolourization of azodye solutions by Fenton's oxidation. Water Research, v. 29, p. 2206-2210, 1995. https://doi.org/10.1016/0043-1354(95)00042-J

TRAMA, B.; FERNANDES, J. D.; LABUTO, G.; DE OLIVEIRA, J. C. F.; VIANA-NIERO, C.; PASCON, R. C.; et al. The Evaluation of Bioremediation Potential of a Yeast Collection Isolated from Composting. Advances in Microbiology, v. 4, p. 796-807, 2014. http://dx.doi.org/10.4236/aim.2014.412088

UMAR, M.; AZIZ, H. A.; YUSOFF, M. S. Trends in the use of Fenton, electro-Fenton and photo-Fenton for the treatment of landfill leachate. Waste Management, v. 30, p. 2113 2121, 2010. https://doi.org/10.1016/j.wasman.2010.07.003

VILLA, R. D.; SILVA, M. R. A. da; NOGUEIRA, R. F. P. Potencial de aplicação do processo foto-fenton/solar como pré-tratamento de efluente da indústria de laticínios. Química Nova, v. 30, p. 1799-1803, 2007. http://dx.doi.org/10.1590/S0100-40422007000800002

WALLING, C.; GOOSEN, A. Mechanism of the ferric ion catalysed decomposition of hydrogen peroxide. Effect of organic substrates. Journal of American Chemical Society, v. 95, p. 2987-2991, 1973. http://dx.doi.org/10.1021/ja00790a042

WANG, J.; CHEN, C. Biosorbents for heavy metals removal and their future. Biotechnology Advances, v. 27, p. 195-226, 2009. https://doi.org/10.1016/j.biotechadv.2008.11.002

WU, Y.; ZHOU, S.; ZHENG, K.; YE, X.; QIN, F. Mathematical model analysis of Fenton oxidation of landfill leachate. Waste Management, v. 31, p. 468-474, 2011. https://doi.org/10.1016/j.wasman.2010.09.016 